\title{
A New Species of Cladolabes (Echinodermata: Holothuroidea: Dendrochirotida: Sclerodactylidae) from Nagasaki, Japan, with Partial Redescription of the Neotype of C. limaconotus
}

\author{
Yusuke Yamana ${ }^{1,3}$, Chikako Iwaoka ${ }^{2}$ and Kanako Hyakutake ${ }^{2}$ \\ ${ }^{1}$ Wakayama Prefectural Museum of Natural History, Funo 370-1, Kainan, Wakayama 642-0001, Japan \\ ${ }^{2}$ Saikai Pearl Sea Resort, Umi Kirara Aquarium, Kashimae 1008, Sasebo, Nagasaki 858-0922, Japan \\ E-mail: yamanamako@gmail.com \\ ${ }^{3}$ Corresponding author
}

(Received 30 June 2013; Accepted 27 February 2014)

\begin{abstract}
We describe the new sclerodactylid sea cucumber Cladolabes kirara sp. nov. based on 10 specimens collected in the intertidal zone of the west coast of Nagasaki Prefecture, Japan. For comparison, we also examined the neotype specimen of Cladolabes limaconotus Brandt, 1835 (type species of the genus) and provide illustrations of the general appearance of its body and of ossicles from a tentacle, the introvert, and the middle part of the body. The new species is readily distinguishable from its congeners by the shape of the ossicles in the integument of the body wall, which are two-pillared tables with rudimentary discs, distally united pillars, and most frequently two holes and a cross-beam between the pillars.
\end{abstract}

Key Words: Echinodermata, Holothuroidea, Dendrochirotida, Sclerodactylidae, Cladolabes kirara sp. nov., taxonomy, new species, Japan.

\section{Introduction}

The taxonomic identity of the dendrochirotid holothurian genus Cladolabes Brandt, 1835, as well as that of its type species, C. limaconotus Brandt, 1835 (type locality: Ogasawara Ids., Japan), was obscured for a long time due to the lack of type material. The genus had often been confused with other genera, such as Urodemas Selenka, 1867 (e.g., Deichmann 1944), before Heding and Panning (1954) re-diagnosed Cladolabes. Their work was based on neotypification of a specimen exhibiting the typical features of C. limaconotus that was collected in 1893 in Nagasaki, Japan, and deposited in the Zoological Museum, University of Copenhagen (ZMUC), Denmark. While Heding and Panning's (1954) new definition has been widely accepted by later researchers (e.g., Cherbonnier 1988), the taxonomy of Cladolabes has been hampered by the highly polymorphic nature of the ossicles and calcareous ring, which can vary drastically within a species (Heding and Panning 1954). Because these are key distinguishing features, a number of ossicles and calcareous rings from many specimens should be examined in order to arrive at a better taxonomy of the species in this genus.

Heding and Panning (1954) assigned eight species to Cladolabes, including the type species, but nine are currently recognized (Paulay 2013), of which C. limaconotus and C. schmeltzii (Ludwig, 1875) have been recorded from Japanese waters (Brandt 1835; Heding and Panning 1954; Imaoka 1995; Imahara 2011, 2013). A species of Cladolabes that we recently found intertidally in Nagasaki, western Japan, turned out to be different not only from both C. limaconotus and C. schmeltzii, but also from all the other congeners. In this paper, we describe this shore-dwelling species as new to science. For comparison, we examined the neotype specimen of $C$. limaconotus, a partial redescription of which is also given.

\section{Materials and Methods}

Ten specimens were collected by staff of the Saikai Pearl Sea Resort, Sasebo, Nagasaki, on 28 March 2013 in the intertidal zone of a boulder shore $\left(33^{\circ} 15^{\prime} 13^{\prime \prime} \mathrm{N}, 129^{\circ} 33^{\prime} 25^{\prime \prime} \mathrm{E}\right)$ on Bojima Island, Kujukushima Islands, near the west coast of Nagasaki Prefecture. We fixed five of the specimens in $80 \%$ ethanol after anaesthetization; the remaining five were fixed without anaesthesia. Anaesthetization was performed in a menthol solution: $0.37 \mathrm{~g}$ of menthol was dissolved into $100 \mathrm{ml}$ of $99 \%$ ethanol, which was diluted to $3.0 \%$ with seawater. The specimens were immersed in the diluted solution for $0.5-1.0 \mathrm{~h}$; when the anaesthesia had taken effect, the tentacles emerged in response to a gentle squeeze of the body. Before fixation, magnesium chloride $\left(\mathrm{MgCl}_{2} \cdot 6 \mathrm{H}_{2} \mathrm{O}\right)$ was added to the solution at a ratio of $3.0 \mathrm{~g}$ per $100 \mathrm{ml}$ for further anaesthetization.

We dissected all 10 specimens and examined the tentacles, the Polian vesicles, the stone canals, and the calcareous rings under a stereoscopic microscope (Nikon SMZ). To observe ossicle morphology, small pieces of tissue were taken from each specimen from the following parts of the 
body (Fig. 1C): 1) the inter-radial tentacle on the abdominal side; 2) the anterior, 3) middle, and 4) posterior parts of the introvert in the inter-radius on the abdominal side; 5) the anterior, 6) middle, and 7) posterior parts of the body-wall integument in the inter-radius on the dorsal side; 8-10) the integument of the same regions of the body on the abdominal side; and 11) pedicels at about mid-length of the body on the abdominal side. The tissue samples were dissolved in hypochlorous acid $(\mathrm{NaClO}, 5 \%)$ under a compound microscope (Nikon Optiphot). Because no obvious differences were found among the ossicles of the 10 specimens examined, those of three paratypes were counted and measured on the basis of photographs. We classified the ossicles into seven types: four types of "table" (i.e., ossicles consisting of a multi-perforated "disc" and a skeleton-constructing "spire" that grows perpendicularly from the disc), two types of "plate" (multi-perforated flat ossicles without a spire), and one type of "rod" (stick-like ossicle, occasionally branched). For every tissue sample, we determined the abundance of each type for a total of 13-100 ossicles-depending on their density-and measured them to the nearest micrometer. The type specimens of the new species and glass slides of their ossicles have been deposited in the Invertebrate Collection (INV) of the Wakayama Prefectural Museum of Natural History (WMNH), in Kainan, Wakayama, Japan.

The neotype specimen of $C$. limaconotus has already been dissected by Heding and Panning (1954); therefore, we were able to examine the tentacles, the Polian vesicles, the stone canals, and the calcareous ring without additional dissection. For observation of the ossicles of the neotype of $C$. limaconotus, small pieces of tissue were taken from a tentacle, the introvert, and the body wall. These were cut from the inter-radius on the abdominal side of the specimen-in the case of the introvert and body, near their mid-length (Fig. 8). Because only a small amount of tissue could be used for ossicle examination, measurements were not carried out.

\section{Cladolabes kirara sp. nov.}

(Figs 1-7)

Material examined. Holotype, WMNH-2013-INV-5 (anaesthetized; length $97.6 \mathrm{~mm}$, width $19.4 \mathrm{~mm}$ ). Paratypes: WMNH-2013-INV-3 (anaesthetized; length $61.2 \mathrm{~mm}$, width $21.7 \mathrm{~mm}$ ); WMNH-2013-INV-4 (anaesthetized; length $120.0 \mathrm{~mm}$, width $31.3 \mathrm{~mm}$ ); WMNH-2013-INV-6 (anaesthetized; length $66.2 \mathrm{~mm}$, width $20.1 \mathrm{~mm}$ ); WMNH2013-INV-7 (anaesthetized; length $86.0 \mathrm{~mm}$, width $19.9 \mathrm{~mm}$ ); WMNH-2013-INV-8 (unanaesthetized; length $43.9 \mathrm{~mm}$, width $28.4 \mathrm{~mm}$ ); WMNH-2013-INV-9 (unanaesthetized; length $34.0 \mathrm{~mm}$, width $18.7 \mathrm{~mm}$ ); WMNH2013-INV-10 (unanaesthetized; length $51.8 \mathrm{~mm}$, width $30.1 \mathrm{~mm}$ ); WMNH-2013-INV-11 (unanaesthetized; length $46.4 \mathrm{~mm}$, width $23.7 \mathrm{~mm}$ ); WMNH-2013-INV-12 (unanaes-

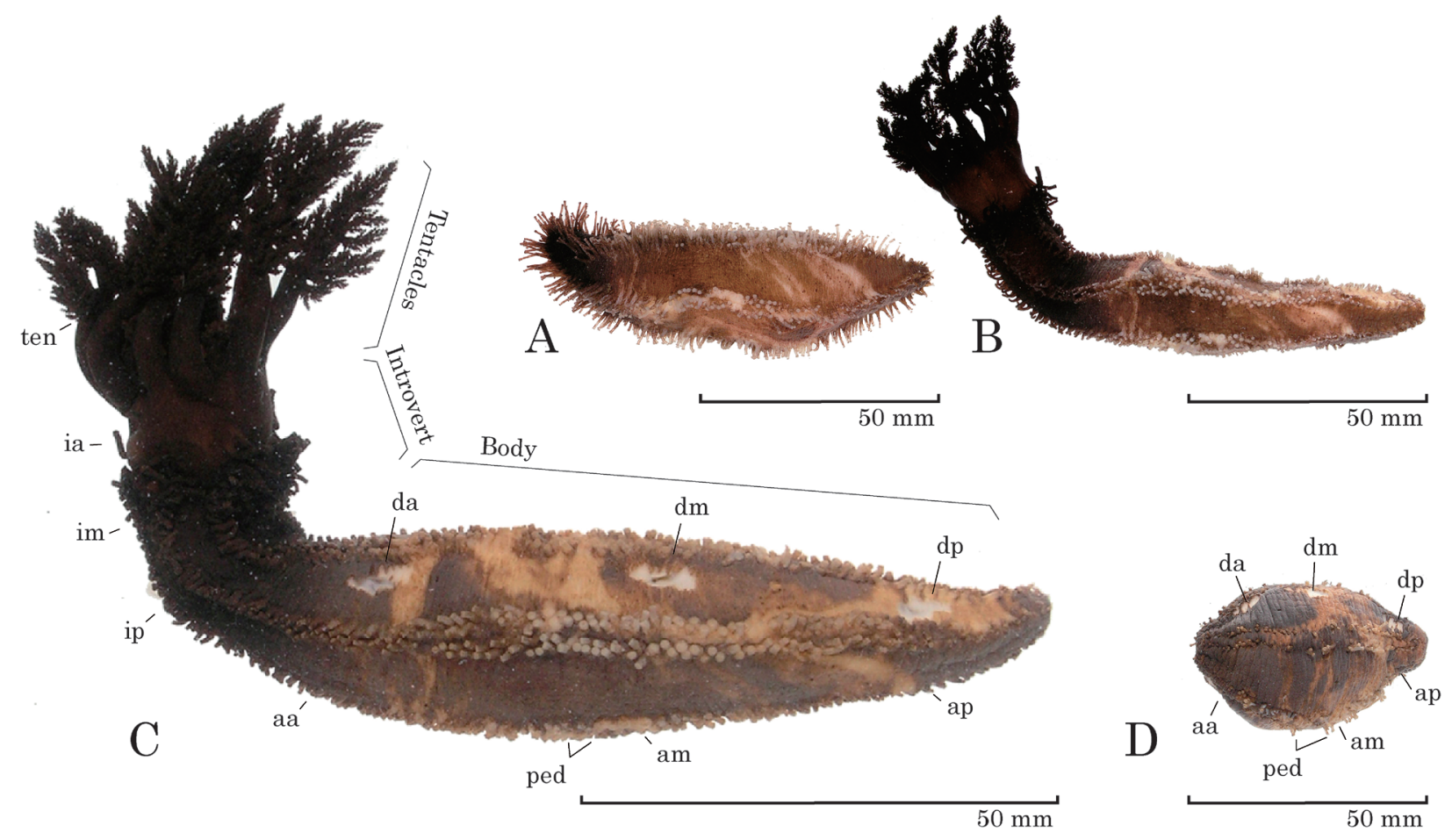

Fig. 1. Cladolabes kirara sp. nov., lateral views, A-C, WMNH-2013-INV-5 (holotype); D, WMNH-2013-INV-10 (paratype). A, B, Living state, before (A) and after (B) anaesthetization; C, preserved state; D, preserved state, fixed without anaesthesia, tentacles and introvert entirely retracted. Abbreviations indicating sites of tissue sampling for ossicle examination: aa, anterior part of body on abdominal side; am, middle part of body on abdominal side; ap, posterior part of body on abdominal side; da, anterior part of body on dorsal side; dm, middle part of body on dorsal side; dp, posterior part of body on dorsal side; ia, anterior part of introvert; im, middle part of introvert; ip, posteror part of introvert; ped, pedicel; ten, tentacle. 


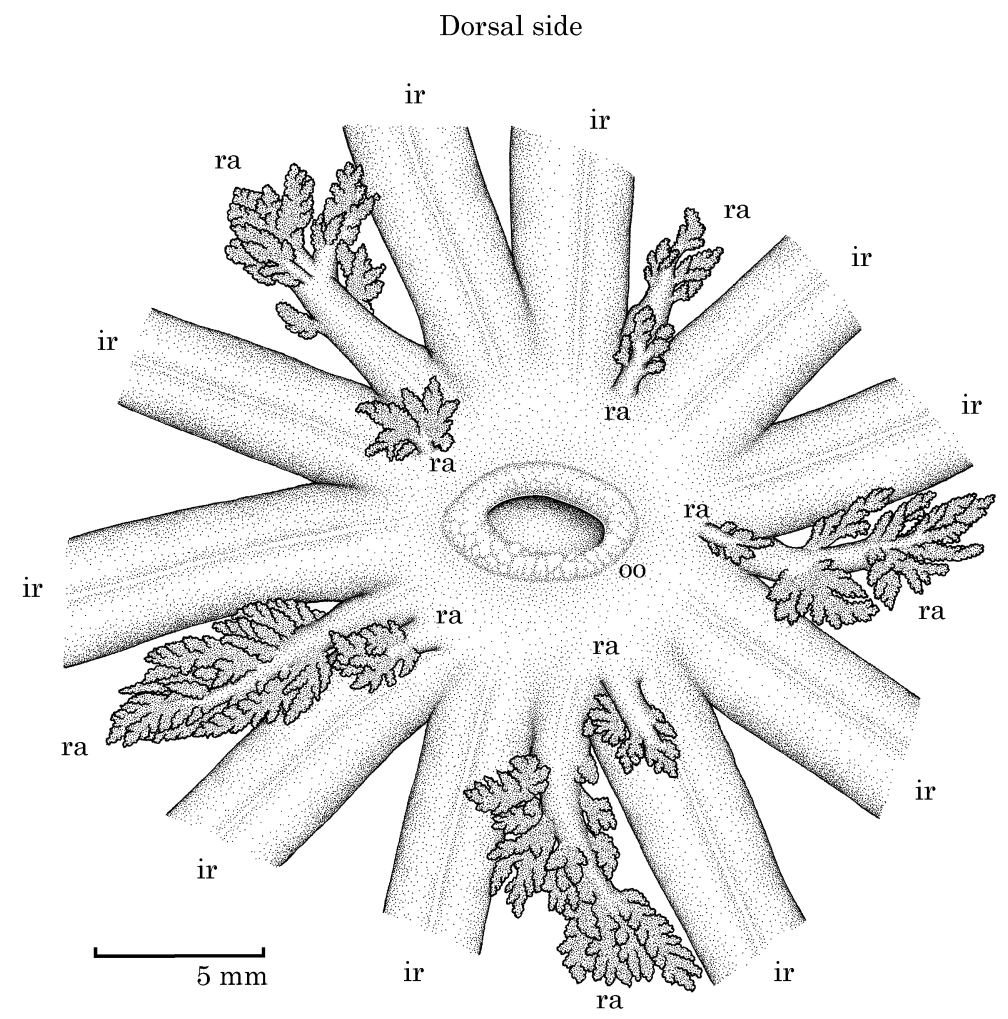

Abdominal side

Fig. 2. Cladolabes kirara sp. nov., WMNH-2013-INV-5 (holotype), showing arrangement of circumoral tentacles. Abbreviations: ir, interradial tentacle; oo, oral opening; ra, radial tentacle.

Table 1. Measurements of body size and radial elements of calcareous ring, as well as counts of pedicels, tentacles, stone canals, and Polian vesicles, in 10 specimens of Cladolabes kirara sp. nov.

\begin{tabular}{|c|c|c|c|c|c|c|c|c|c|c|c|}
\hline \multirow{2}{*}{$\begin{array}{l}\text { Type } \\
\text { status }\end{array}$} & \multirow{2}{*}{$\begin{array}{l}\text { Registration } \\
\text { number } \\
\text { (WMNH) }\end{array}$} & \multirow{2}{*}{ Condition } & \multicolumn{2}{|c|}{ Body size (mm) } & \multicolumn{2}{|c|}{$\begin{array}{l}\text { Number of } \\
\text { pedicels in } \\
\text { each row }\end{array}$} & \multicolumn{2}{|c|}{$\begin{array}{c}\text { Size of calcareous- } \\
\text { ring radial } \\
\text { element }(\mathrm{mm})\end{array}$} & \multirow{2}{*}{$\begin{array}{c}\text { Number of } \\
\text { tentacles }\end{array}$} & \multirow{2}{*}{$\begin{array}{l}\text { Number } \\
\text { of stone } \\
\text { canals }\end{array}$} & \multirow{2}{*}{$\begin{array}{r}\text { Number } \\
\text { of Polian } \\
\text { vesicles }\end{array}$} \\
\hline & & & Length & Width & Body & $\begin{array}{c}\text { Intro- } \\
\text { vert }\end{array}$ & Length & Width & & & \\
\hline holotype & 2013-INV-5 & anaesthetized & 97.6 & 19.4 & $75-93$ & $20-27$ & 8.1 & 2.3 & 20 & $>50$ & 20 \\
\hline paratype & 2013-INV-3 & anaesthetized & 61.2 & 21.7 & $49-72$ & $11-16$ & 6.7 & 2.0 & 20 & $>50$ & $>8$ \\
\hline paratype & 2013-INV-4 & anaesthetized & 120.0 & 31.3 & $88-103$ & $25-32$ & 8.4 & 2.3 & 20 & $>50$ & 20 \\
\hline paratype & 2013-INV-6 & anaesthetized & 66.2 & 20.1 & $45-59$ & $10-15$ & 7.2 & 1.4 & 20 & $>30$ & $>13$ \\
\hline paratype & 2013-INV-7 & anaesthetized & 86.0 & 19.9 & $68-77$ & $9-15$ & 5.0 & 0.1 & 20 & $>5$ & $>18$ \\
\hline paratype & 2013-INV-8 & unanaesthetized & 43.9 & 28.4 & $?$ & $?$ & 7.8 & 2.1 & 20 & $>30$ & 20 \\
\hline paratype & 2013-INV-9 & unanaesthetized & 34.0 & 18.7 & $?$ & $?$ & 5.8 & 1.6 & 20 & $>30$ & $>16$ \\
\hline paratype & 2013-INV-10 & unanaesthetized & 51.8 & 30.1 & $?$ & $?$ & 8.8 & 2.5 & 20 & $>50$ & $>8$ \\
\hline paratype & 2013-INV-11 & unanaesthetized & 46.4 & 23.7 & $?$ & $?$ & 6.7 & 2.4 & 20 & $>30$ & $>10$ \\
\hline paratype & 2013-INV-12 & unanaesthetized & 48.3 & 20.8 & ? & ? & 5.8 & 0.7 & 20 & $>20$ & $>15$ \\
\hline
\end{tabular}

WMNH: Wakayama Prefectural Museum of Natural History.

thetized; length $48.3 \mathrm{~mm}$, width $20.8 \mathrm{~mm}$ ).

Description. Appearance of anaesthetized specimens not drastically changed by fixation; general colour also not much affected by fixation/preservation (Fig. 1A-C). Tentacles and introvert dark brown. Twenty dendritic tentacles in double circle $(15+5)$, including five pairs of large interradial tentacles and five single small radial tentacles in outer circle and five very small radial tentacles in inner circle (Fig. 2). Body fusiform, generally variegated with blackish-grey and ochre-yellow colours; mouth anterior, anus posterior, no anal teeth; pedicels forming two longitudinal rows along each radius throughout entire body length, each row with approximately $60-130$ pedicels (Fig. 1A-D, Table 1).

Radial elements of calcareous ring each composed of 


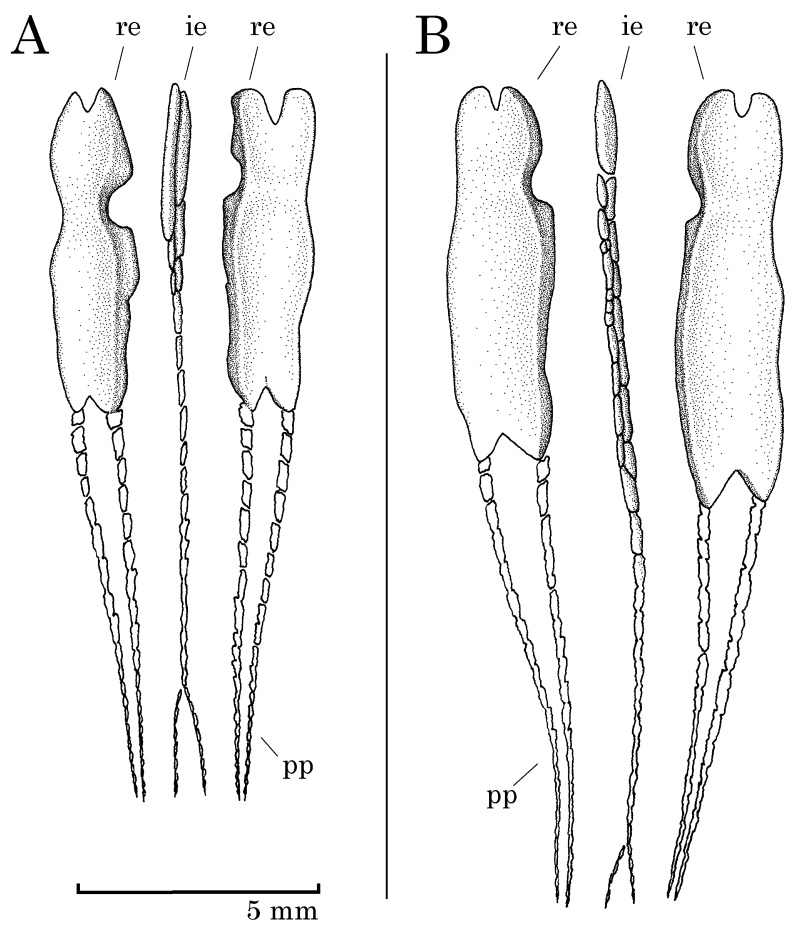

Fig. 3. Cladolabes kirara sp. nov., elements of calcareous rings, viewed from body cavity. A, Abdominal elements, WMNH2013-INV-3 (paratype); B, dorsal elements, WMNH-2013-INV-8 (paratype). Abbreviations: ie, inter-radial element; pp, posterior prolongation; re, radial element. large, slender piece, constricted in middle of its anterior half, with anterior and posterior notches and with pair of long, narrow, fragile chains of small, thin, spongiform segments attached posteriorly (Fig. 3A, B); shorter radial elements tending to be narrower (Table 1). Inter-radial elements of calcareous ring with no large piece, composed of single, posteriorly bifurcate chain of small, thin, spongiform segments.

Up to 20 Polian vesicles and more than 30 stone canals present, fewer in smaller specimens (Table 1; these all entangled and difficult to count accurately); gonad tubules branched.

Only one type of ossicle found in abdominal-side interradial tentacle: finely branched rods, mean length $53-63 \mu \mathrm{m}$, mean width of central stem $3.5-4.3 \mu \mathrm{m}$ (Fig. $4 \mathrm{~A}$, B, Table 2 ). No large rods such as those found in some species of the dendrochirotid genus Colochirus Troschel, 1846 confirmed in any specimen.

Two types of ossicle present in introvert: 1) two-pillared tables with short spire and large disc, and 2) two-pillared tables with high spire and rudimentary disc (Fig. 5A, B, Table $3)$. In three counted paratypes, former type of ossicle dominant in anterior part of introvert: mean abundance there of tables with short spires $93-100 \%$, mean width of discs 80-91 $\mu \mathrm{m}$, mean number of disc holes 3.7-8.1, all depending on specimen. Latter type of ossicle abundant posteriorly in introvert: mean abundance there of tables with high
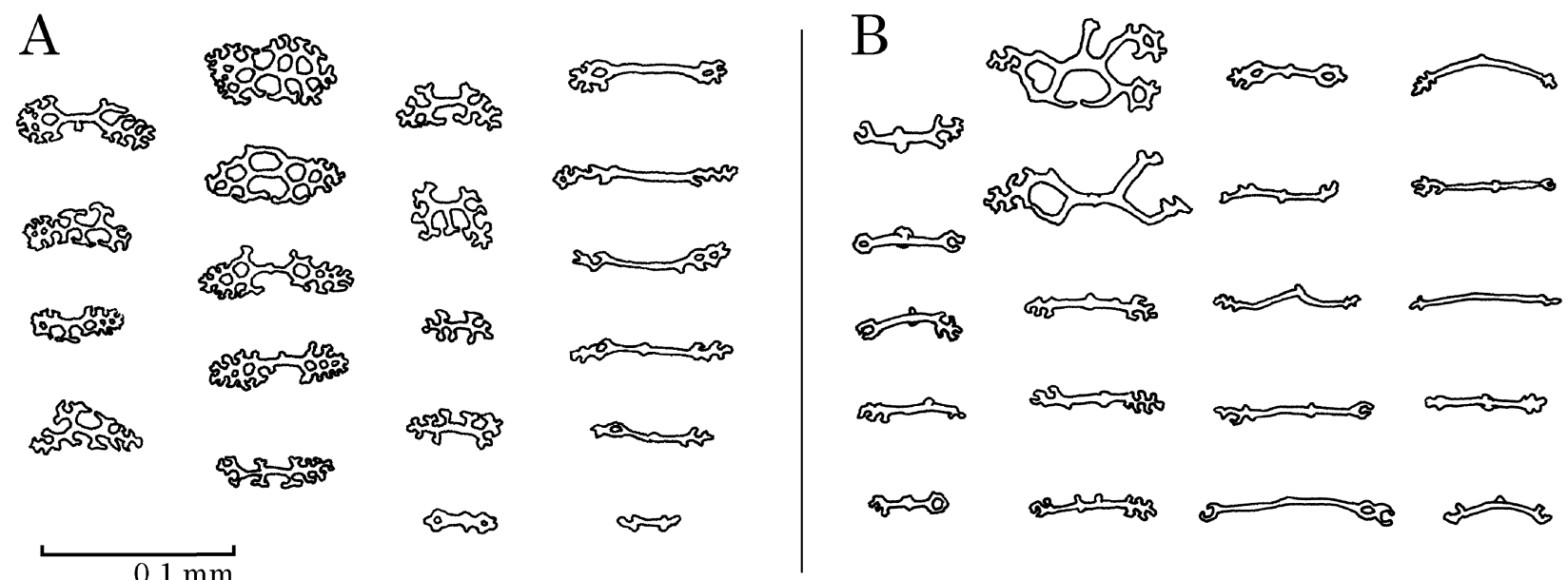

Fig. 4. Cladolabes kirara sp. nov., ossicles of inter-radial tentacle on abdominal side. A, WMNH-2013-INV-7 (paratype); B, WMNH2013-INV-10 (paratype).

Table 2. Abundance (\%) and size $(\mu \mathrm{m})$ of ossicles in inter-radial tentacle in three paratype specimens of Cladolabes kirara sp. nov.

\begin{tabular}{|c|c|c|c|c|}
\hline & & & Length & Width \\
\hline Registration number & Ossicle type & $\begin{array}{l}\% \\
(n)\end{array}$ & $\begin{array}{c}\text { Mean } \pm \text { SD } \\
\text { (Range) }\end{array}$ & $\begin{array}{c}\text { Mean } \pm \text { SD } \\
\text { (Range) }\end{array}$ \\
\hline WMNH-2013-INV-3 & Rod & $\begin{array}{l}100 \\
(80)\end{array}$ & $\begin{array}{c}53 \pm 16 \\
(11-106)\end{array}$ & $\begin{array}{c}3.5 \pm 1.5 \\
(1-8)\end{array}$ \\
\hline WMNH-2013-INV-6 & Rod & $\begin{array}{l}100 \\
(44)\end{array}$ & $\begin{array}{r}56 \pm 15 \\
(30-88)\end{array}$ & $\begin{array}{c}4.3 \pm 1.3 \\
(2-8)\end{array}$ \\
\hline WMNH-2013-INV-10 & Rod & $\begin{array}{l}100 \\
(44)\end{array}$ & $\begin{array}{c}63 \pm 14 \\
(36-106)\end{array}$ & $\begin{array}{c}4.3 \pm 1.2 \\
(2-7)\end{array}$ \\
\hline
\end{tabular}



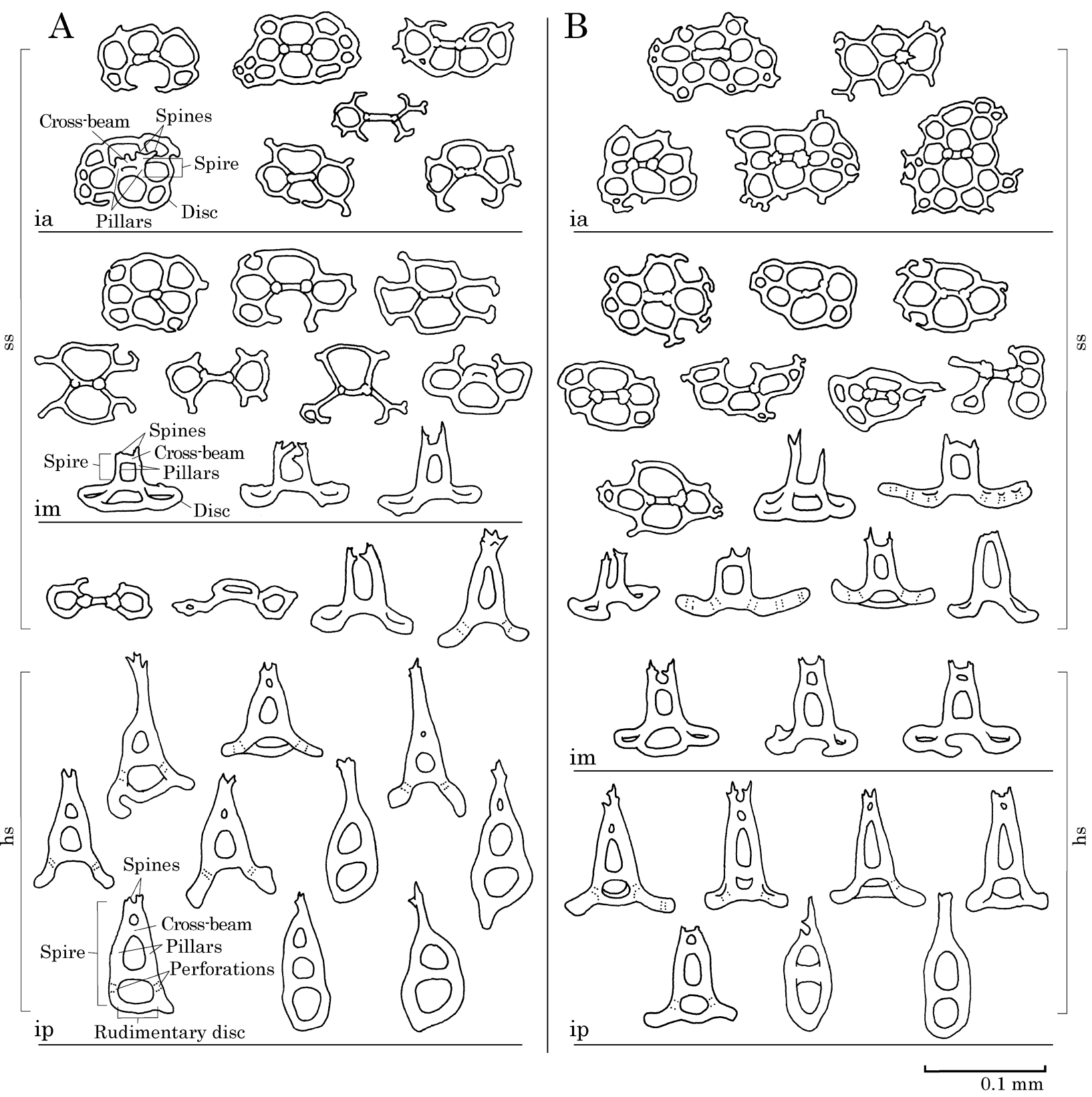

Fig. 5. Cladolabes kirara sp. nov., ossicles of inter-radius of introvert on abdominal side. A, WMNH-2013-INV-7 (paratype); B, WMNH2013-INV-10 (paratype). Abbreviations: hs, two-pillared table with high spire (containing two to three cross-beams [or holes]) and a rudimentary disc; ia, ossicles in anterior part of introvert; im, ossicles in middle part of introvert; ip, ossicles in posterior part of introvert; ss, twopillared table with short spire (containing zero to one cross-beams [or holes]) and a large disc.

spires $23-100 \%$, mean width of discs $57-78 \mu \mathrm{m}$, mean number of disc holes $0.9-2.7$, depending on specimen.

Mainly two types of ossicle found in body integument: 1) two-pillared tables with rudimentary discs and distally united pillars; and 2) two-pillared tables with completely degenerated discs (Fig. 6A, B, Table 4). Abundance of each type significantly different among three specimens observed $\left(\chi^{2}\right.$ test, $P<0.05$ ), but not among six sites in the body ( $\chi^{2}$ test, $P>0.05)$. Former ossicle type dominant at all six sites: mean abundance $68-97 \%$, depending on specimen, with row of one to five holes between two thick pillars $(52-73 \%$ with two holes, depending on specimen). Height and width of those with two holes significantly different among the three specimens (Kruskal-Wallis test, $P<0.05$ ), but not among the six body sites (Kruskal-Wallis test, $P>0.05$ ): mean height $102-126 \mu \mathrm{m}$, mean width $42-47 \mu \mathrm{m}$, depending on specimen. Latter type of ossicle less abundant: mean abundance 3-27\%, depending on specimen. Pillars of both types of ossicle frequently with small lateral perforations, and also frequently with several apical spines (cf. Fig. 5, ip).

Mainly three types of ossicle present in pedicels: 1 ) endplates, 2) plates, and 3) two-pillared tables with rudimentary discs (Fig. 7A, B, Table 5). Tables abundant, $50-64 \%$ in total in three examined paratypes; endplates and plates less common. Shape of tables variable, mostly with two holes. Endplates with approximately 276-906 holes (mean 499-827, 
Table 3. Abundance $(\%)$ and size $(\mu \mathrm{m})$ of ossicles from introvert and number of holes in disc of ossicles in three paratypes of Cladolabes kirara sp. nov.

\begin{tabular}{|c|c|c|c|c|c|c|c|c|c|c|}
\hline \multirow{3}{*}{$\begin{array}{l}\text { Registration } \\
\text { number }\end{array}$} & \multirow{3}{*}{$\begin{array}{l}\text { Ossicle } \\
\text { type }\end{array}$} & \multicolumn{3}{|c|}{ Anterior part of introvert } & \multicolumn{3}{|c|}{ Middle part of introvert } & \multicolumn{3}{|c|}{ Posterior part of introvert } \\
\hline & & $\%$ & Width & $\begin{array}{c}\text { Number of } \\
\text { holes }\end{array}$ & $\%$ & Width & $\begin{array}{c}\text { Number of } \\
\text { holes }\end{array}$ & $\%$ & Width & $\begin{array}{c}\text { Number of } \\
\text { holes }\end{array}$ \\
\hline & & $(n)$ & $\begin{array}{c}\text { Mean } \pm \text { SD } \\
\text { (Range) }\end{array}$ & $\begin{array}{c}\text { Mean } \pm \text { SD } \\
\text { (Range) }\end{array}$ & $(n)$ & $\begin{array}{c}\text { Mean } \pm \text { SD } \\
\text { (Range) }\end{array}$ & $\begin{array}{c}\text { Mean } \pm S D \\
\text { (Range) }\end{array}$ & $(n)$ & $\begin{array}{c}\text { Mean } \pm S D \\
\text { (Range) }\end{array}$ & $\begin{array}{c}\text { Mean } \pm S D \\
\text { (Range) }\end{array}$ \\
\hline \multirow{2}{*}{$\begin{array}{l}\text { WMNH- } \\
\text { 2013-INV-3 }\end{array}$} & Table $^{\mathrm{a}}$ & $\begin{array}{c}93 \\
(28)\end{array}$ & $\begin{array}{c}83 \pm 17 \\
(51-125)\end{array}$ & $\begin{array}{c}3.7 \pm 2.1 \\
(0-8)\end{array}$ & $\begin{array}{c}77 \\
(20)\end{array}$ & $\begin{array}{c}81 \pm 7 \\
(70-99)\end{array}$ & $\begin{array}{c}3.9 \pm 1.3 \\
(2-8)\end{array}$ & $\begin{array}{c}26 \\
(10)\end{array}$ & $\begin{array}{c}94 \pm 22 \\
(64-122)\end{array}$ & $\begin{array}{c}2.2 \pm 1.7 \\
(0-5)\end{array}$ \\
\hline & Table $^{\mathrm{b}}$ & $\begin{array}{c}7 \\
(2)\end{array}$ & $\begin{array}{c}85 \\
(66-104)\end{array}$ & $\begin{array}{c}2.0 \\
(1-3)\end{array}$ & $\begin{array}{l}23 \\
(6)\end{array}$ & $\begin{array}{l}64 \pm 15 \\
(47-87)\end{array}$ & $\begin{array}{c}3.3 \pm 1.5 \\
(2-5)\end{array}$ & $\begin{array}{c}74 \\
(28)\end{array}$ & $\begin{array}{l}57 \pm 15 \\
(35-82)\end{array}$ & $\begin{array}{c}0.9 \pm 0.9 \\
(0-3)\end{array}$ \\
\hline \multirow{2}{*}{$\begin{array}{l}\text { WMNH- } \\
\text { 2013-INV-6 }\end{array}$} & Table ${ }^{\mathrm{a}}$ & $\begin{array}{l}100 \\
(39)\end{array}$ & $\begin{array}{c}80 \pm 9 \\
(66-103)\end{array}$ & $\begin{array}{c}4.1 \pm 1.4 \\
(2-8)\end{array}$ & $\begin{array}{c}88 \\
(30)\end{array}$ & $\begin{array}{c}78 \pm 10 \\
(63-101)\end{array}$ & $\begin{array}{c}4.0 \pm 1.6 \\
(2-9)\end{array}$ & $\begin{array}{c}77 \\
(10)\end{array}$ & $\begin{array}{c}77 \pm 16 \\
(45-103)\end{array}$ & $\begin{array}{c}3.6 \pm 1.0 \\
(2-5)\end{array}$ \\
\hline & Table ${ }^{\mathrm{b}}$ & $\begin{array}{c}0 \\
(0)\end{array}$ & - & - & $\begin{array}{l}12 \\
(4)\end{array}$ & $\begin{array}{c}77 \pm 9 \\
(63-101)\end{array}$ & $\begin{array}{c}2.8 \pm 0.9 \\
(2-4)\end{array}$ & $\begin{array}{l}23 \\
(3)\end{array}$ & $\begin{array}{c}76 \pm 5 \\
(72-82)\end{array}$ & $\begin{array}{c}2.7 \pm 0.6 \\
(2-3)\end{array}$ \\
\hline \multirow{2}{*}{$\begin{array}{l}\text { WMNH- } \\
\text { 2013-INV-10 }\end{array}$} & Table ${ }^{\mathrm{a}}$ & $\begin{array}{l}100 \\
(9)\end{array}$ & $\begin{array}{c}91 \pm 19 \\
(66-118)\end{array}$ & $\begin{array}{c}8.1 \pm 5.0 \\
(3-16)\end{array}$ & $\begin{array}{c}87 \\
(40)\end{array}$ & $\begin{array}{c}92 \pm 15 \\
(63-146)\end{array}$ & $\begin{array}{c}4.0 \pm 1.8 \\
(1-7)\end{array}$ & $\begin{array}{c}0 \\
(0)\end{array}$ & - & - \\
\hline & Table ${ }^{b}$ & $\begin{array}{c}0 \\
(0)\end{array}$ & - & $\begin{array}{l}- \\
-\end{array}$ & $\begin{array}{l}13 \\
(6)\end{array}$ & $\begin{array}{c}84 \pm 9 \\
(74-99)\end{array}$ & $\begin{array}{c}2.2 \pm 0.4 \\
(2-3)\end{array}$ & $\begin{array}{l}100 \\
(16)\end{array}$ & $\begin{array}{c}78 \pm 9 \\
(68-95)\end{array}$ & $\begin{array}{c}2.5 \pm 0.8 \\
(2-4)\end{array}$ \\
\hline
\end{tabular}

aTwo-pillared, with short spire with $0-1$ cross-beams (or holes).

${ }^{b}$ Two-pillared, with high spire with 2-4 cross-beams (or holes).

depending on specimen); diameter $415-703 \mu \mathrm{m}$ (mean 567$663 \mu \mathrm{m}$, depending on specimen). Plates with 2-19 holes (mean 6.4-9.1, depending on specimen); width 101-238 $\mu \mathrm{m}$ (mean 140-165 $\mu \mathrm{m}$, depending on specimen).

Distribution. So far known only from the type locality, Bojima Island, west coast of Nagasaki Prefecture, Kyushu, Japan.

Ecology. At the type locality, the new species co-occurred with the following species of sea cucumbers: Holothuria (Lessonothuria) pardalis Selenka, 1867, Afrocucumis africana (Semper, 1867), Stolus buccalis (Stimpson, 1855), and Lipotrapeza sp.

Etymology. The specific name kirara, a noun in apposition from the Japanese, meaning "mica" or alluding to "the state or quality of being beautifully shiny", was given after the name of the aquarium of the Saikai Pearl Sea Resort, which is near the sampling site.

Cladolabes limaconotus Brandt, 1835

(Figs 8-10)

Cladolabes limaconctos [sic] Brandt, 1835: 57 (“limacontos" in footnote).

Cladolabes limaconotos [sic] Brandt 1836: 187 (indicated as "Nov. spec.").

Cladolabes limacondos [sic]: Selenka 1867: 331.

Holothuria limaconotus: Selenka 1867: 331.

Orcula limaconotus: Ludwig 1881: 589.

Phyllophorus limaconotus: Oshima 1918: 147.

Cladolabes limaconotus: Heding and Panning 1954: 123; Imaoka 1995: 557; Rowe and Gates 1995: 322.

Material examined. ZMUC-HOL-301, neotype, July 1893, 25 fathoms (i.e., ca. $46 \mathrm{~m}$ ) deep, $33^{\circ} 5^{\prime} \mathrm{N}, 128^{\circ} 22^{\prime} \mathrm{E}$,
Nagasaki, Japan.

Description. Body $150 \mathrm{~mm}$ long, $50 \mathrm{~mm}$ wide, fusiform, curved, mouth anterior, anus posterior, no anal teeth; body colour bleached brown; pedicels around body, not radial (Fig. 8). Twenty dendritic tentacles in double circle $(15+5)$. Numerous Polian vesicles and stone canals. Main part of calcareous ring consisting of 10 elements (five radii+five inter-radii), thick, not fragmented, possessing very short, thin, spongiform posterior prolongations (Fig. 9). Only one type of ossicle in examined tentacle: finely branched rods (Fig. 10A). Introvert with two type of ossicles: 1) two-pillared tables with large disc and short spire; and 2) two-pillared tables with small disc and spire ending in cluster of spines (Fig. 10B). Body-wall integument mainly with one type of ossicle: two-pillared tables with small disc and spire ending in cluster of spines (Fig. 10C).

Distribution. Boulder shore of Ogasawara (Bonin) Islands (Brandt 1835); offshore of Nagasaki, 25 fathoms (i.e., ca. $46 \mathrm{~m}$ ) deep (Heding and Panning 1954).

Remarks. The morphological account given by Heding and Panning (1954) was so precise and accurate that our observation yielded no taxonomic novelty or necessity for correction. However, the photograph of the general appearance of the body (Fig. 8), as well as the newly reported ossicle morphology of a tentacle and the introvert (Fig. $10 \mathrm{~A}, \mathrm{~B})$, may be useful in future studies of the systematics of Cladolabes.

Nomenclature. Due to wide acceptance by later authors, we consider that the specific name limaconotus should be maintained as valid, as stipulated in Article 33.3.1 of the International Code of Zoological Nomenclature (ICZN 1999), although this spelling is not from Brandt's (1835) original work, but from Selenka (1867). In the original de- 


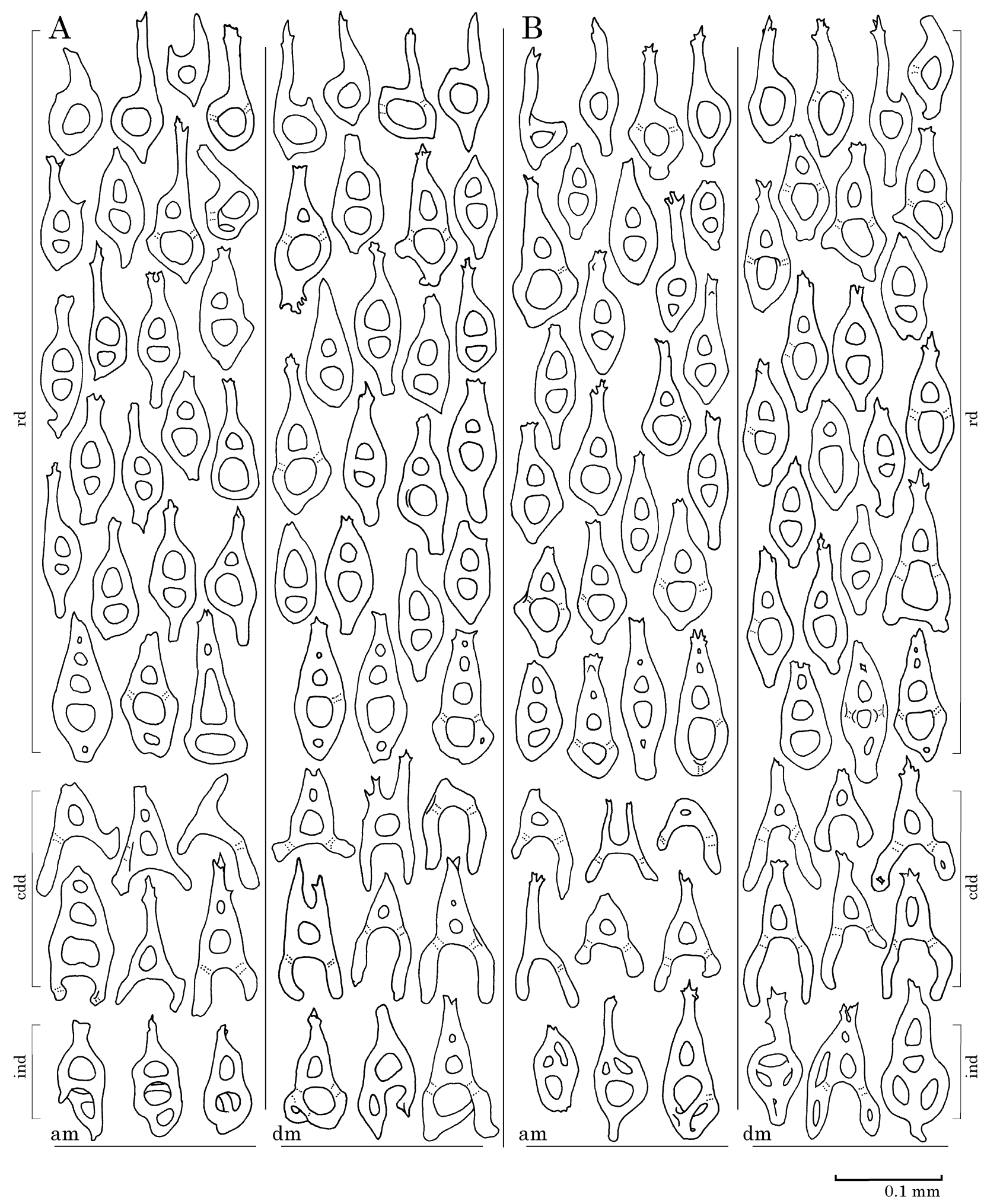

Fig. 6. Cladolabes kirara sp. nov., integument ossicles of inter-radius in middle part of body. A, WMNH-2013-INV-7 (paratpe); B, WMNH-2013-INV-10 (paratype). Abbreviations: am, ossicles in middle part of body on abdominal side; cdd, two-pillared table with completely degenerated disc; rd, two-pillared table with rudimentary disc; $\mathrm{dm}$, ossicles in middle part of body on dorsal side; ind, table with indeterminate shape.

scription, Brandt (1835) gave the etymology in a footnote, stating (in Latin) that the name alludes to the similarity of the appearance of the dorsum of this new holothurian to that of slugs. Although significantly disturbed by printer's errors in the original description-limaconctos in the heading and limacontos in the footnote (Brandt 1835: 257)-, neither of which spelling contains a Latin or Greek root referring to "dorsum", the author's true intention appears to 


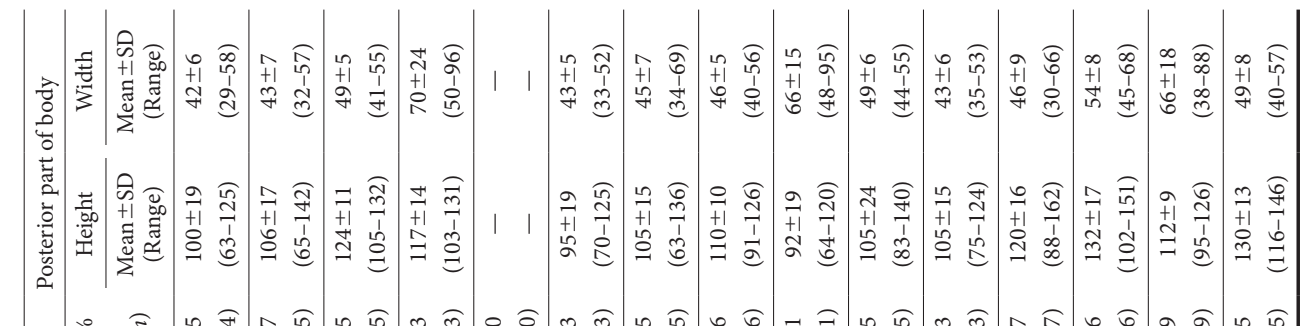

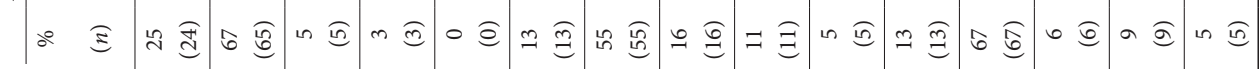

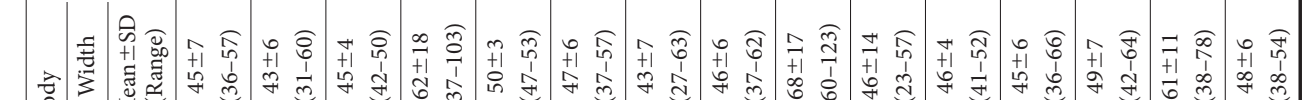
$\frac{\square}{\mathscr{n}}$

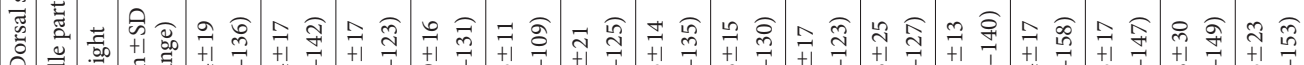

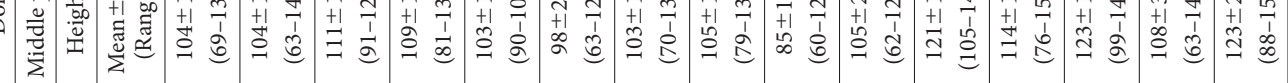

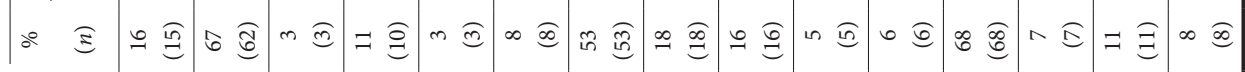

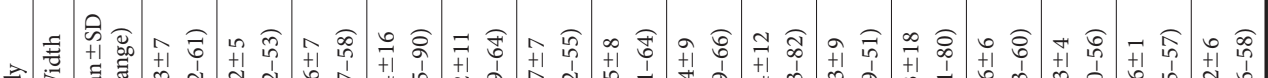

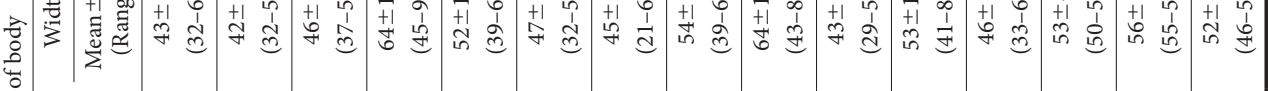

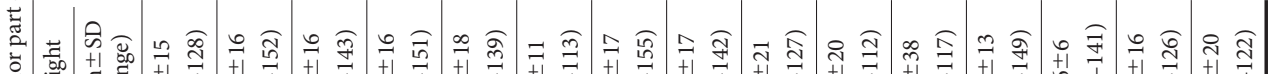

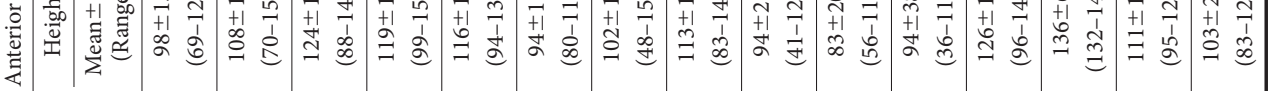

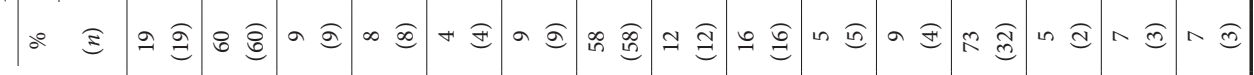

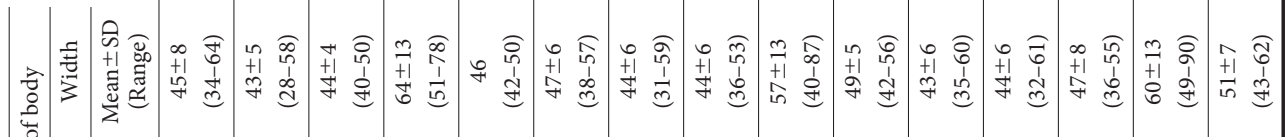

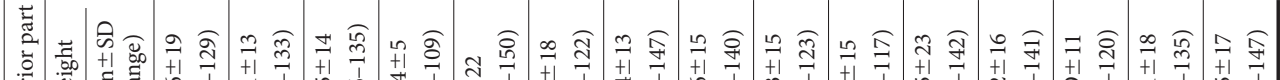

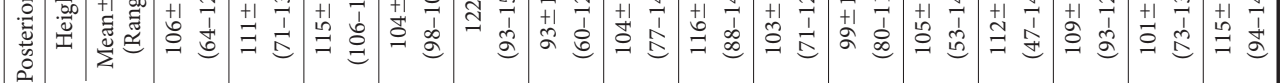

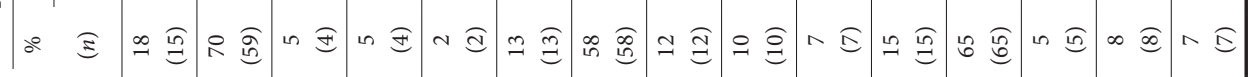

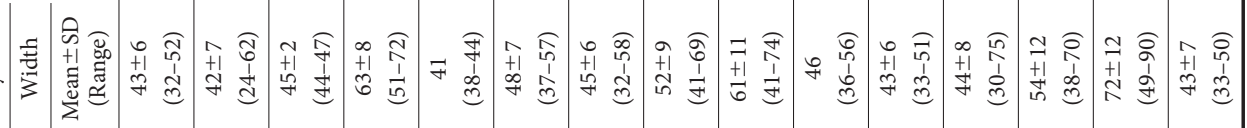

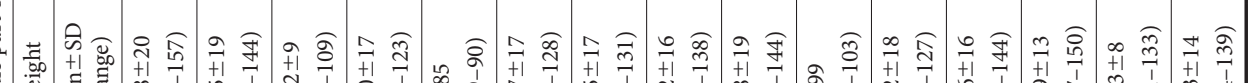

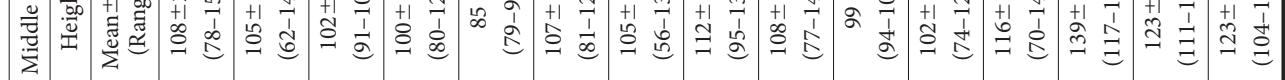

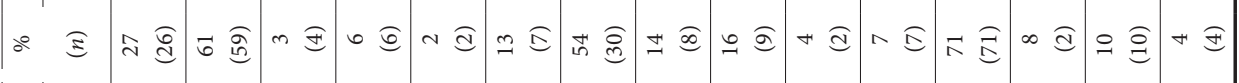

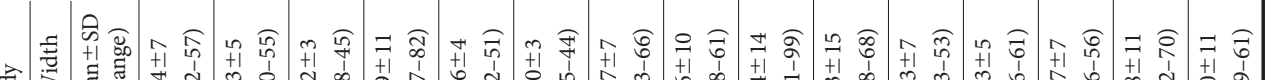

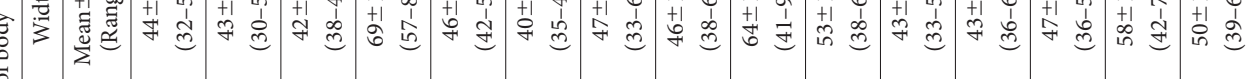
莺

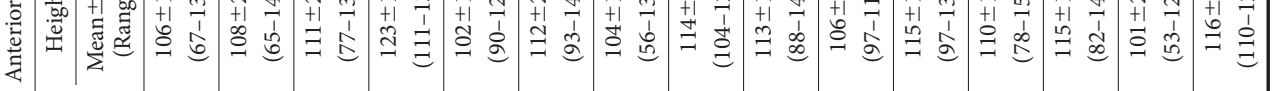

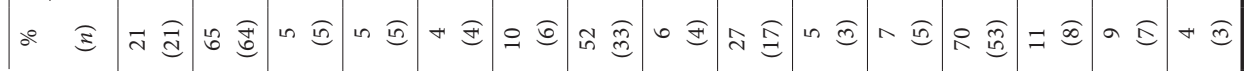

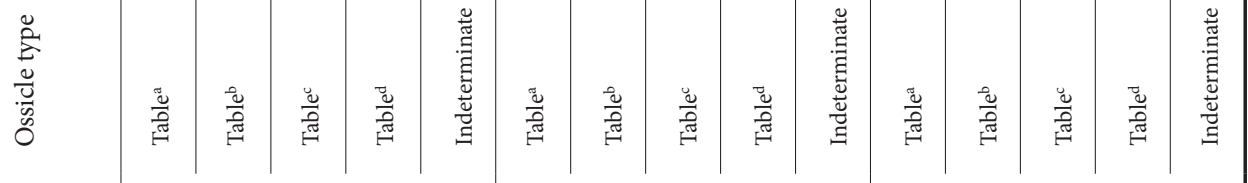

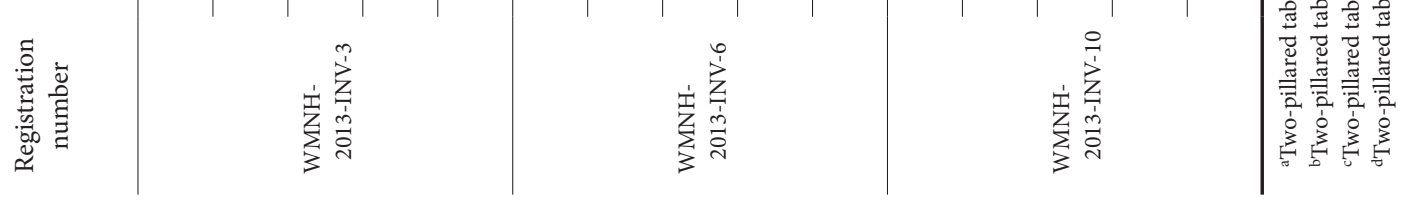



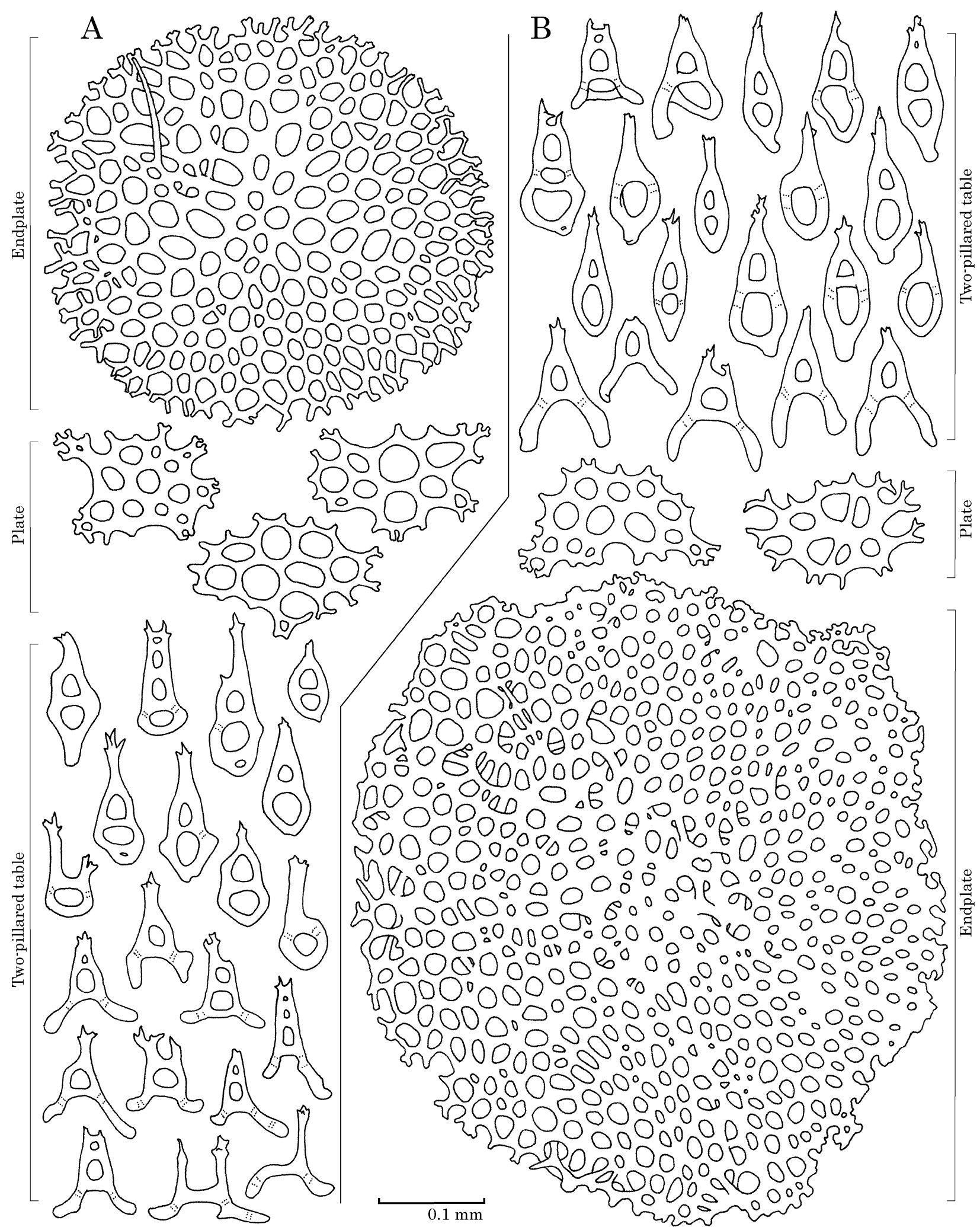

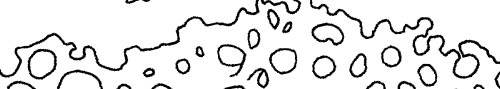

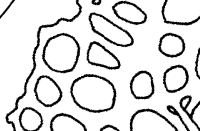

$5000090000000000000000.000\}$ 500000000000000000003

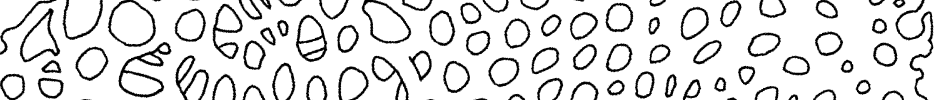

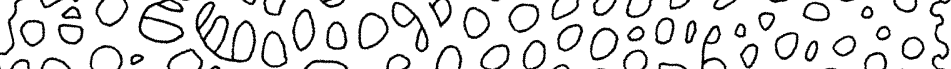

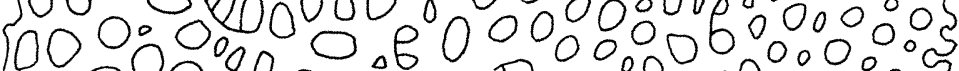
o 00000000.00000000000 ,

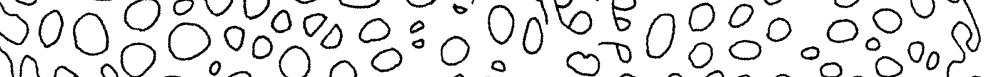

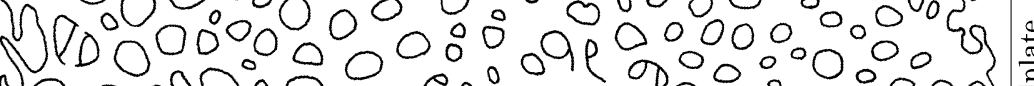

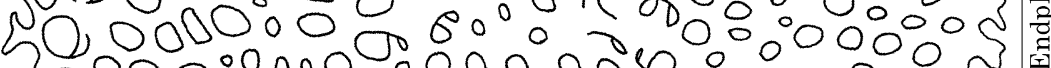

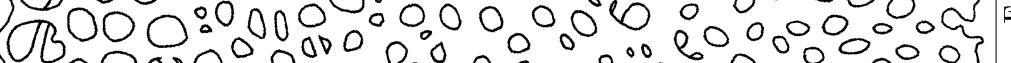

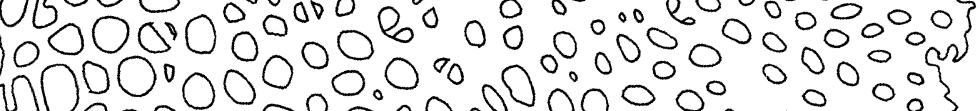

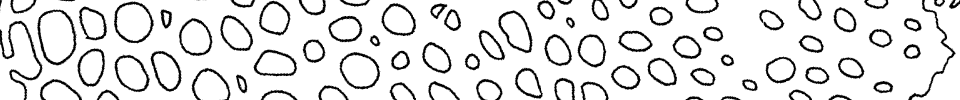

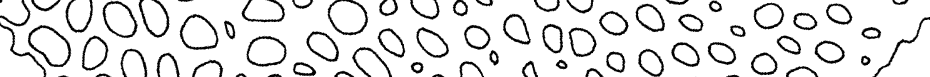

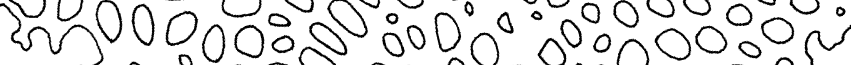
$20000000000000000 \mathrm{~s}$

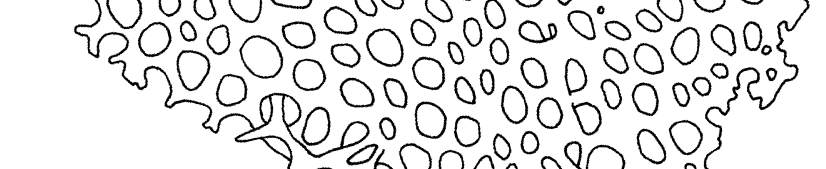

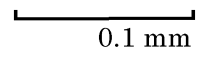

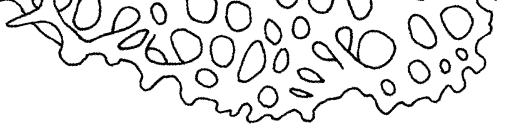

Fig. 7. Cladolabes kirara sp. nov., ossicles in pedicels from middle part of body on abdominal side. A, WMNH-2013-INV-7 (paratype); B, WMNH-2013-INV-10 (paratype).

have been actualized in the succeeding publication (Brandt 1836), namely limaconotos, which is clearly derived from limacis (Latin, "of slug") and notos (Greek, "dorsum"). Nonetheless, this latter spelling cannot be adopted as the "correct original spelling" because it was not a demonstrably intentional correction (i.e., not an emendation) and because incorrect transliteration (to "nctos" or "ntos" instead of "notos") is not considered an inadvertent error (Article 
Table 5. Abundance $(\%)$ and size $(\mu \mathrm{m})$ of ossicles in pedicels in middle part of body and number of holes in plates of ossicles in three paratypes of Cladolabes kirara sp. nov.

\begin{tabular}{|c|c|c|c|c|c|c|}
\hline & & $\%$ & Diameter ${ }^{\mathrm{a}}$ & Number of holes ${ }^{b}$ & Height & Width \\
\hline Registration number & Ossicle type & $(n)$ & $\begin{array}{c}\text { Mean } \pm S D \\
\text { (Range) }\end{array}$ & $\begin{array}{c}\text { Mean } \pm \text { SD } \\
\text { (Range) }\end{array}$ & $\begin{array}{c}\text { Mean } \pm S D \\
\text { (Range) }\end{array}$ & $\begin{array}{c}\text { Mean } \pm S D \\
\text { (Range) }\end{array}$ \\
\hline \multirow{6}{*}{ WMNH-2013-INV-3 } & Endplate & $\begin{array}{c}9 \\
(7)\end{array}$ & $\begin{array}{c}567 \pm 86 \\
(415-671)\end{array}$ & $\begin{array}{l}499 \pm 164 \\
(276-704)\end{array}$ & - & - \\
\hline & Plate & $\begin{array}{c}28 \\
(21)\end{array}$ & - & $\begin{array}{c}9.1 \pm 5.7 \\
(2-19)\end{array}$ & - & $\begin{array}{c}161 \pm 32 \\
(119-238)\end{array}$ \\
\hline & Table & $\begin{array}{c}15 \\
(11)\end{array}$ & - & - & $\begin{array}{c}97 \pm 14 \\
(80-128)\end{array}$ & $\begin{array}{c}43 \pm 6 \\
(36-53)\end{array}$ \\
\hline & Table $^{\mathrm{d}}$ & $\begin{array}{c}31 \\
(23)\end{array}$ & - & - & $\begin{array}{c}100 \pm 16 \\
(68-128)\end{array}$ & $\begin{array}{c}41 \pm 8 \\
(29-61)\end{array}$ \\
\hline & Table ${ }^{e}$ & $\begin{array}{c}4 \\
(3)\end{array}$ & - & - & $\begin{array}{c}102 \pm 36 \\
(69-140)\end{array}$ & $\begin{array}{c}43 \pm 3 \\
(40-45)\end{array}$ \\
\hline & Others $^{\mathrm{f}}$ & $\begin{array}{l}12 \\
(9)\end{array}$ & - & - & $\begin{array}{c}88 \pm 19 \\
(66-131)\end{array}$ & $\begin{array}{l}80 \pm 15 \\
(55-99)\end{array}$ \\
\hline \multirow{6}{*}{ WMNH-2013-INV-6 } & Endplate & $\begin{array}{l}11 \\
(5)\end{array}$ & $\begin{array}{c}636 \pm 15 \\
(623-653)\end{array}$ & $\begin{array}{c}827 \pm 63 \\
(746-906)\end{array}$ & - & - \\
\hline & Plate & $\begin{array}{l}18 \\
(8)\end{array}$ & - & $\begin{array}{c}6.6 \pm 3.0 \\
(4-13)\end{array}$ & - & $\begin{array}{c}140 \pm 25 \\
(101-173)\end{array}$ \\
\hline & Table ${ }^{c}$ & $\begin{array}{c}7 \\
(3)\end{array}$ & - & - & $\begin{array}{c}89 \pm 20 \\
(69-109)\end{array}$ & $\begin{array}{l}47 \pm 11 \\
(38-59)\end{array}$ \\
\hline & Table $^{\mathrm{d}}$ & $\begin{array}{c}36 \\
(16)\end{array}$ & - & - & $\begin{array}{c}101 \pm 17 \\
(70-129)\end{array}$ & $\begin{array}{c}41 \pm 7 \\
(28-59)\end{array}$ \\
\hline & Table $e^{e}$ & $\begin{array}{l}13 \\
(6)\end{array}$ & - & - & $\begin{array}{c}127 \pm 22 \\
(108-165)\end{array}$ & $\begin{array}{c}45 \pm 9 \\
(32-55)\end{array}$ \\
\hline & Others $^{\mathrm{f}}$ & $\begin{array}{l}16 \\
(7)\end{array}$ & - & - & $\begin{array}{c}97 \pm 17 \\
(81-126)\end{array}$ & $\begin{array}{l}63 \pm 18 \\
(44-88)\end{array}$ \\
\hline \multirow{6}{*}{ WMNH-2013-INV-10 } & Endplate & $\begin{array}{c}5 \\
(4)\end{array}$ & $\begin{array}{c}663 \pm 39 \\
(613-703)\end{array}$ & $\begin{array}{c}637 \pm 66 \\
(549-707)\end{array}$ & - & - \\
\hline & Plate & $\begin{array}{c}12 \\
(10)\end{array}$ & - & $\begin{array}{c}6.4 \pm 3.8 \\
(2-13)\end{array}$ & - & $\begin{array}{c}165 \pm 32 \\
(105-210)\end{array}$ \\
\hline & Table & $\begin{array}{l}11 \\
(9)\end{array}$ & - & - & $\begin{array}{l}112 \pm 12 \\
(92-127)\end{array}$ & $\begin{array}{c}44 \pm 4 \\
(39-51)\end{array}$ \\
\hline & Table $^{\mathrm{d}}$ & $\begin{array}{c}44 \\
(36)\end{array}$ & - & - & $\begin{array}{c}121 \pm 18 \\
(73-150)\end{array}$ & $\begin{array}{l}42 \pm 10 \\
(25-78)\end{array}$ \\
\hline & Table & $\begin{array}{c}9 \\
(7)\end{array}$ & - & - & $\begin{array}{c}127 \pm 7 \\
(114-137)\end{array}$ & $\begin{array}{c}47 \pm 7 \\
(37-59)\end{array}$ \\
\hline & Others $^{\mathrm{f}}$ & $\begin{array}{c}19 \\
(15)\end{array}$ & - & - & $\begin{array}{c}100 \pm 30 \\
(44-145)\end{array}$ & $\begin{array}{c}69 \pm 20 \\
(36-122)\end{array}$ \\
\hline \multicolumn{7}{|c|}{$\begin{array}{l}\text { a Measured along major axis. } \\
\text { bexhaustive count or, in case of broken endplates, estimated by } \\
\text { bxho-pillared table with } 1 \text { hole, with rudimentary disc. } \\
\text { dTwo-pillared table with } 2 \text { holes, with rudimentary disc. } \\
\text { dTwo-pillared table with } 3-5 \text { holes, with rudimentary disc. }\end{array}$} \\
\hline
\end{tabular}

32.5.1). The original footnote did not include the Greek word "notos", either in the Greek or Latin alphabet, which would have provided clear evidence of an inadvertent error. Without explanation, Selenka (1867) altered the ending from -os to - $u s$, probably trying to avoid a Latin-Greek hybrid. This incorrect subsequent spelling (Article 33.3), limaconotus, was consistently adopted by later workers, however (e.g., Ludwig 1881: 589; Lampert 1885: 169; Théel 1886: 149; see also the synonymy above). As a result of this prevailing usage (under Article 33.3.1), it is to be main- 


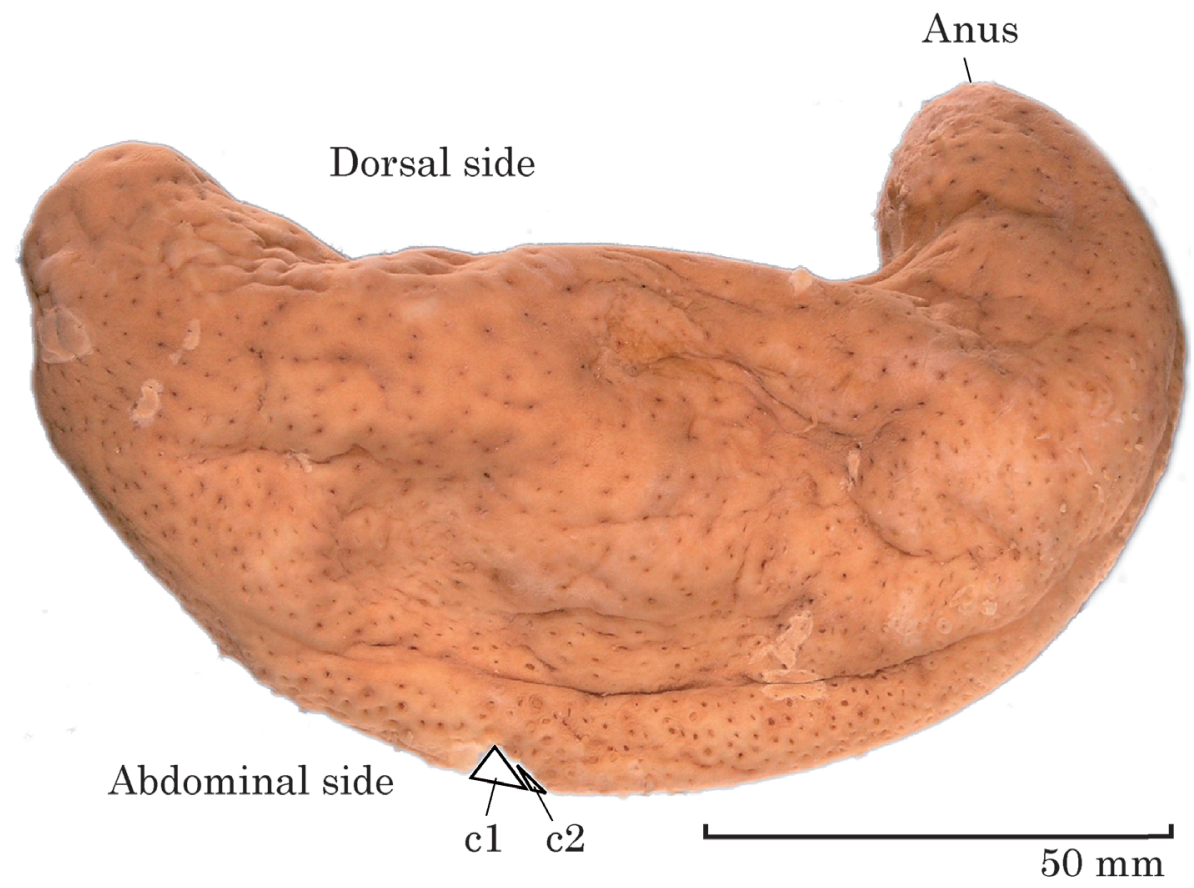

Fig. 8. Cladolabes limaconotus Brandt, 1835, ZMUC-HOL-301 (neotype), lateral view (tentacles and introvert entirely retracted). Abbreviations: c1, area of integument cut out by Heding and Panning (1954); c2, area cut out in the present study.

tained as valid.

\section{Discussion}

Heding and Panning (1954) diagnosed Cladolabes as follows: body size small to medium, with 20 tentacles arranged in double or triple circles $(15+5$ or $10+5+5)$; numerous Polian vesicles and stone canals; main part of calcareous ring consisting of 10 elements (five radii+five inter-radii), these long, more or less spongiform, and not fragmented; each element of calcareous ring possessing paired or unpaired, long and narrow posterior prolongations; body wall containing derivatives of tables with a small disc, with a spire comprising two pillars fused into a single rod- or club-shaped structure and ending in a single spine or a cluster of spines; introvert containing two-pillared tables with a larger disc and shorter spires; and tentacles containing finely branching rods. Our new species should be included in Cladolabes because it mostly agrees with this diagnosis, except for the calcareous ring. While Heding and Panning (1954) diagnosed it as "not fragmented" in Cladolabes, in most species of Sclerodactylidae, including Cladolabes, the posterior prolongations of the calcareous ring are actually sometimes fragmented to some degree, although not to the degree of forming a mosaic pattern or stone pavement. We regard the calcareous ring of the examined 10 specimens of the new species as being not clearly fragmented. However, we do not know whether the calcareous rings of the present specimens are fully developed, and the possibility still remains that the calcareous ring of the new species possesses "not fragmented" elements, just as the neotype of Cladolabes

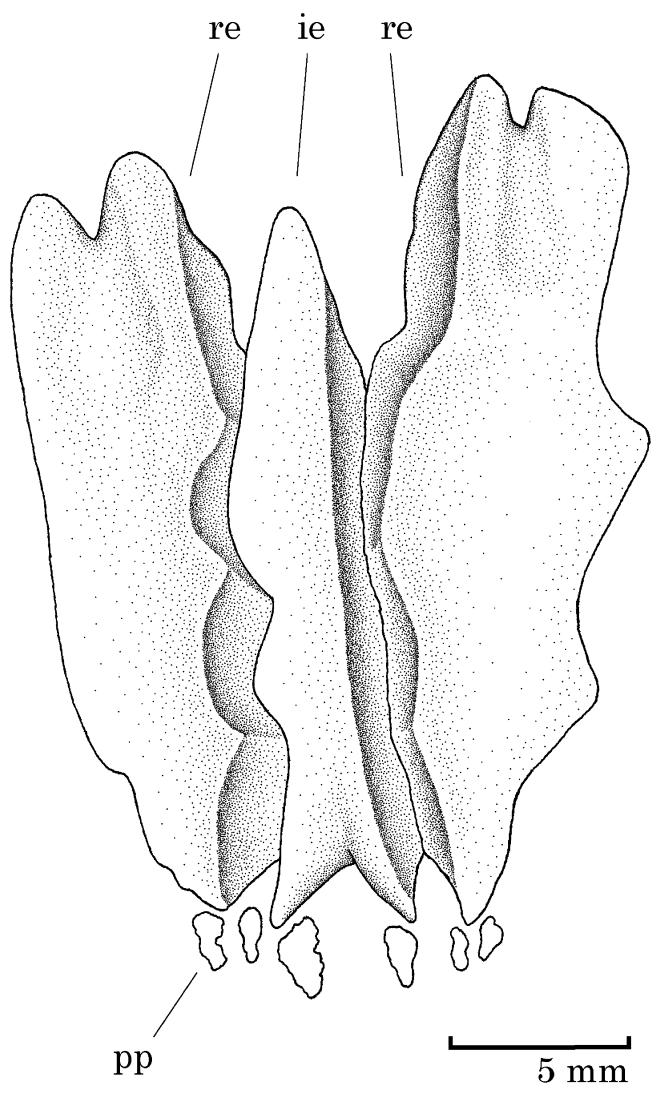

Fig. 9. Cladolabes limaconotus Brandt, 1835, ZMUC-HOL-301 (neotype), elements of calcareous ring, viewed from body cavity. Abbreviations: ie, inter-radial element; pp, posterior prolongation; re, radial element. 

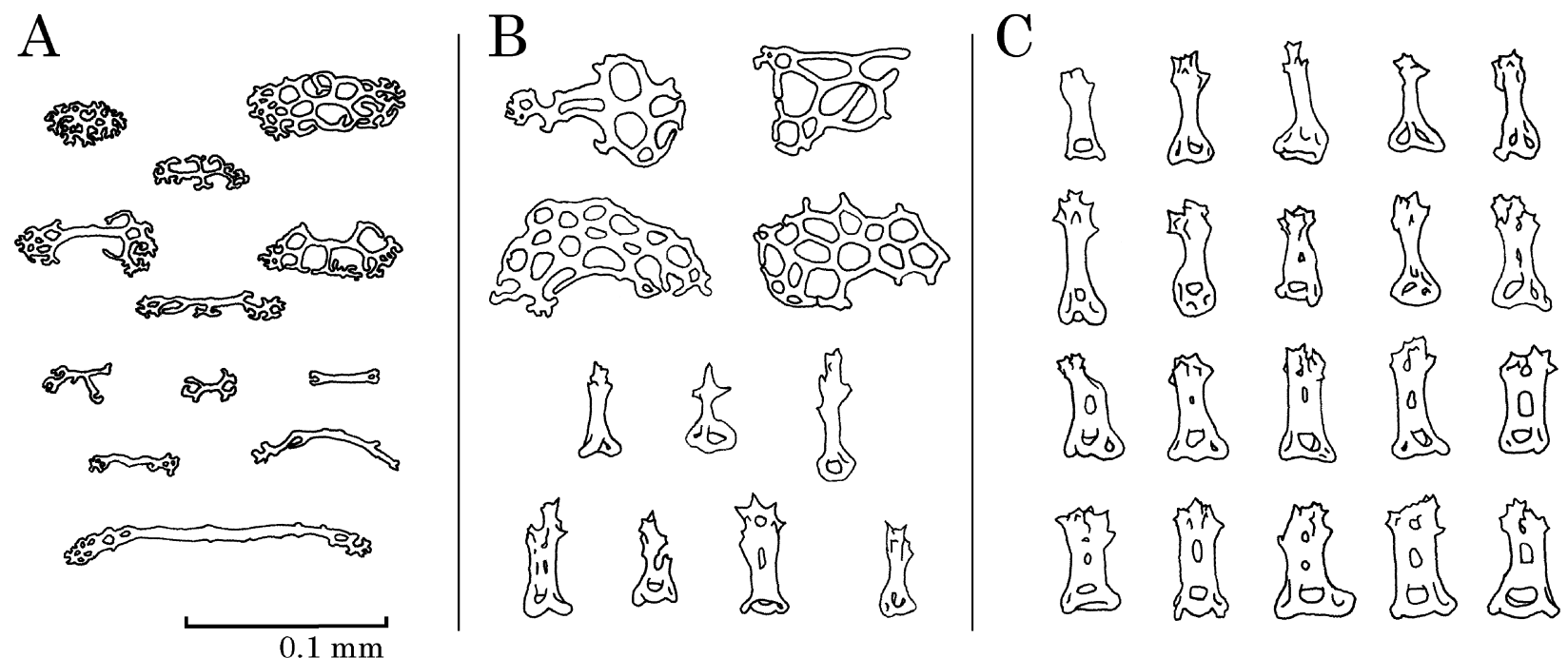

Fig. 10. Cladolabes limaconotus Brandt, 1835, ZMUC-HOL-301 (neotype), ossicles of inter-radius on abdominal side of tentacle (A), middle part of introvert (B), and middle part of body (C).

limaconotus does.

Among the material examined, some specimens had smaller calcareous ring elements than usual, and also fewer Polian vesicles and stone canals (Table 1). This may be the result of regeneration, since autotomy and evisceration are not unusual in many holothurians (e.g., Pawson 1966). These variable features cannot serve reliably to distinguish Cladolabes kirara sp. nov. from its congeners.

The new species is clearly different from Cladolabes $i-$ maconotus, regardless of the geographical closeness of their locality. In the present study, we observed differences in the arrangement of the pedicels, and in the shape of the ossicles in the integument.

In the new species, the pedicels are clearly arranged in two rows along each radius. In the previously known congeners, only three species, viz., C. aciculus (Semper, 1868), C. pichoni Cherbonnier, 1988, and C. roxasi (Domantay, 1934), exhibit the same arrangement (Semper 1868; Domantay 1934; Cherbonnier 1988). The other species of Cladolabes have pedicels that are either spread evenly over the radius and inter-radius, as in C. crassus (Clark, 1938), C. hamatus (Sluiter, 1914), C. limaconotus, and C. schmeltzii; or spread in zones on each side of the radius, as in C. bifurcatus (Deichmann, 1944) and C. perspicillum (Selenka, 1867) (Brandt 1835; Selenka 1867; Ludwig 1875; Sluiter 1914; Clark 1938; Deichmann 1944).

The 20 tentacles of the new species are arranged in two concentric circles $(15+5)$. Only two congeners, $C$. limaconotus and $C$. hamatus, are known to have the same tentacle arrangement. In the other species, the tentacles are arranged in triple circles $(10+5+5)$. While this is a taxonomically useful feature, it can be difficult to observe depending on the state of contraction of the specimen.

In the new species, most of the ossicles in the body-wall integument have rudimentary discs, which are sometimes completely degenerated (Fig. 6A, B, Table 4). This is not uncommon in Cladolabes. The ossicles in the previously described species are mostly tables with rudimentary discs, while those of C. aciculus and C. pichoni have no disc at all. The ossicles in the new species have from one to five, but most frequently two, holes positioned in a row between the two thick pillars, the hole being separated by cross-beams (Fig. 6A, B, Table 4). This is apparently unique in the genus. The previously known species mostly have ossicles with a spire comprising two pillars fused into a single rod- or clubshaped structure with no holes between the pillars. In $C$. aciculus, C. hamatus, C. limaconotus, C. perspicillum, and C. pichoni, some ossicles have a row of holes between the two pillars, but these holes are clearly smaller than those in the new species, and the shape of the ossicles is completely different. The ossicles of the new species are not club-like, unlike those of all its congeners, and they therefore serve as a key distinguishing feature.

\section{Acknowledgments}

We are grateful to Dr Tom Schiøtte for providing us the opportunity to examine the neotype of C. limaconotus deposited in ZMUC, and Mr Tohru Imaoka for providing the required documents and information. We thank Mr Akihiro Kawakubo, Mr Keiji Kadowaki, Ms Namiko Nishimura, Ms Satomi Nomiyama, Ms Kumiko Kato, and the staff of Saikai Pearl Sea Resort, Umi Kirara Aquarium, for collecting samples and supporting this study. We also thank Dr François Michonneau and an anonymous reviewer for reviewing the manuscript. Part of the microscopic observation was financially supported by Mr Shinichi Ikebe, of the Supporters' Association of WMNH.

\section{References}

Brandt, J. F. 1835. Prodromus Descriptionis Animalium ab H. Mertensio 
in Orbis Terrarum Circumnavigatione Observatorum. Fasciculus I. Polypos, Acalephas Discophoras et Siphonophoras, nec non Echinodermata continens. Imperial Academy of Sciences, St. Petersburg, $75 \mathrm{pp}$. [Also paginated 203-275 in a different edition (but with the same content), which might have been published in an unknown periodical.]

Brandt, J. F. 1836. Conspectus sectionum, generum, subgenerum et specierum novorum, quae in fasciculo primo Prodromi descriptionum animalium a Mertensio in orbis terrarum circumnavigatione observatorum reperiuntur. Annales des Sciences Naturelles, Zoologie 5: 180-188.

Cherbonnier, G. 1988. Echinodermes: Holothurides. Faune de Madagascar 70: 1-292.

Clark, H. L. 1938. Echinoderms from Australia. Memoirs of the Museum of Comparative Zoology at Harvard College 55: 1-596.

Deichmann, E. 1944. Urodemas bifurcatum, a new holothurian from South Africa, with a revision of the genus Urodemas Selenka. Annals and Magazine of Natural History, 11th Series 11: 731-737.

Domantay, J. S. 1934. Four additional species of littoral Holothurioidea of Port Galera Bay and adjacent waters. Contribution from the Department of Zoology, College of Liberal Arts, University of the Philippines 4: 109-115.

Heding, S. G. and Panning, A. 1954. Phyllophoridae. Spolia Zoologica Musei Hauniensis 13: 1-209.

ICZN [International Commission on Zoological Nomenclature] 1999. International Code of Zoological Nomenclature, Fourth Edition. International Trust for Zoological Nomenclature, London, $306 \mathrm{pp}$.

Imahara, Y. 2011. Holothuroidea. Pp. 155-158. In: Imahara, Y. (Ed.) A Color Guide to the Rocky Shores of Japan. Tombow Shuppan, Osaka, 271 pp. [In Japanese]

Imahara, Y. 2013. Holothuroidea. Pp. 155-158. In: Imahara, Y. (Ed.) A Color Guide to the Rocky Shores of Japan, field edition. Tombow Shuppan, Osaka, 279 pp. [In Japanese]
Imaoka, T. 1995. Holothuroidea. Pp. 553-572. In: Nishimura, S. (Ed.) Guide to Seashore Animals of Japan with Color Pictures and Keys. Vol. II. Hoikusha, Osaka, 663 pp. [In Japanese]

Lampert, K. 1885. Die Seewalzen (Holothurioidea). Eine systematische Monographie. Pp. 1-312 In: Semper C. (Ed.) Holothurien. Reisen im Archipel der Philippinen, Teil 2, Wissenschaftliche Resultate. C. W. Kreidel, Wiesbaden, Bd. 4,3.

Ludwig, H. 1875. Beiträge zur Kenntnis der Holothurien. Arbeiten aus dem Zoologisch-Zootomischen Institut in Würzburg 2: 77-118.

Ludwig, H. 1881. Revision der Mertens-Brandtschen Holothurien. Zeitschrift für Wissenschaftliche Zoologie 35: 575-599.

Oshima, H. 1918. [Holothuroidea in northwest Pacific. XX]. Dobutsugaku Zasshi 31: 139-149. [In Japanese]

Paulay, G. 2013. Cladolabes Brandt, 1835. Accessed through World Register of Marine Species at http://www.marinespecies.org/aphia. php? $=$ taxdetails\&id $=205251$ (4 July 2013).

Pawson, D. L. 1966. Ecology of holothurians. Pp. 63-72. In: Boolootian, R. A. (Ed.) Physiology of Echinodermata. John Wiley \& Sons, Inc., New York.

Rowe and Gates 1995. Echinodermata. In: Wells, A. (Ed.) Zoological Catalogue of Australia. Vol. 33. CSIRO, Melbourne, 510 pp.

Selenka, E. 1867. Beiträge zur Anatomie und Systematik der Holothurien. Zeitschrift für Wissenschaftliche Zoologie 17: 291-374.

Semper, C. 1868. Holothurien. Reisen im Archipel der Philippinen, Teil 2, Wissenschaftliche Resultate. C. W. Kreidel, Wiesbaden, 288 pp.

Sluiter, C. P. 1914. Die von Dr. P. N. van Kampen, während seiner Fahrten mit dem Regierungsdampfer "Gier", 1906-1909, im Indischen Archipel gesammelten Holothurien. Contributions à la Faune Indes Néerlandaises 1: 1-28.

Théel, Hj. 1886. Report on the Holothurioidea dredged by H.M.S. Challenger during the years 1873-76. Report of the Scientific Results of the Exploring Voyage of H.M.S. Challenger during the Years 1873-76. Zoology 39: 1-290. 